\title{
Effect of Human Beta Defensin-2 in Epithelial Cell Lines Infected with Respiratory Viruses
}

Miguel Ángel Galván Morales ${ }^{1}$, Alejandro Escobar Gutiérrez ${ }^{2}$, Dora Patricia Rosete Olvera ${ }^{1}$ and Carlos Cabello Gutiérrez ${ }^{1 *}$

${ }^{1}$ Department of Virology and Mycology Research, National Institute of Respiratory Diseases, Ismael Cosio Villegas, Calzada de Tlalpan, Mexico

${ }^{2}$ Department of Immunological Research, National Institute for Epidemiological Diagnosis and Reference Manuel Martinez Baez, Francisco de P. Miranda 177bis, Mexico

\begin{abstract}
$\beta$-defensins are a family of antimicrobial molecules involved in inflammatory processes and infections. In human airways, $\beta$-defensin-2 (h $\beta \mathrm{D}-2)$ is the best characterized in bacterial and fungal infections; however, it has been insufficiently studied in viral infections. The respiratory syncytial virus (RSV) and adenoviruses (ADV) are important agents of acute respiratory infections. The aim of this study was to measure in vitro the production and antiviral activity of hßD-2 in HEp-2 cells and A549 cells infected with ADV and RSV; $h \beta D-2$ production at different times was assessed by RT-PCR, and its presence by immunodetection assay (Western blot) using antibodies anti-hBD-2. The effect of this defensin on viral replication was determined using recombinant $h \beta D-2$ in plaque assays. The results revealed that in the cell lines production of $\mathrm{h} \beta \mathrm{D}$-2is up regulated after ADV or RSV infection, in direct proportion to the exposure time to each virus. The use of a high concentration of recombinant $h \beta D-2$ resulted in less deleterious viral effect on the cells. The results suggest that both viruses induce $h \beta D-2$ production, no matter if the virus is enveloped or not, and that presence of hBD-2 reduces replication and cytopathic in vitro effect of RSV and ADV. The $\mathrm{h} \beta \mathrm{D}-2$ production by low pathogenicity viruses or live viral vaccines can be useful as therapeutic tools in some infectious diseases.
\end{abstract}

Keywords: Human $\beta$-defensin-2; Airways; Respiratory viruses; Respiratory syncytial virus; Adenovirus

\section{Introduction}

The defensins of vertebrate animals are small, cationic, and amphipathic peptides that contain 18-45 amino acid residues. They comprise three subfamilies, called a, b, and h-defensins. Each subfamily has a conserved motif that includes six cysteine residues that form three intramolecular disulfide bonds with a characteristic and different pattern of pairing. Additional families of small, cysteine-rich antimicrobial peptides (AMPs) exist in plants, fungi, myxobacteria, and invertebrates, including several that are also called defensins $[1,2]$. Are the first line of innate defense against microbial attack by the formation of pores in the plasma membrane, hydrophobic interaction (electrostatic) in infectious agents [3]. Also as carpet adheres to the membrane lipid producing neutralizing negative charges (acting as detergent) and their ability to oligomerize [4]. Also it has positive selection N-terminal helix peptide specific against some bacteria [5]. Furthermore chemotactic activity is not well understood but, in tests however showed that disulfide bonds showed chemotactic properties in monocytes and cells with receptors CCR6 and disulfide peptides showing deficiencies were inactive [6,7]. Depending topology disulfide bridges has designated its chemotactic features especially the similarity to MIP-3 $\alpha$ [8]. They are classified into three groups: $\alpha, \beta$ and $\theta$-defensins. In humans there are $33 \beta$-defensins and are named as $h \beta D$ 1-3 and from the $\mathrm{h} \beta \mathrm{D}-4$ as 104 to 133 , displaying activities over a broad variety of infectious agents, mainly gram-positive and gram-negative bacteria and fungi [9]. However, their blocking effects on viruses still are not fully understood [10], but they depend on direct effect, immune responsive cells interference and induction of cytokine production.

Some viral acute infections on respiratory airways represent a serious health problem, in special respiratory syncytial virus (RSV) and adenoviruses (ADV) which are able to infect the upper and lower airways [11-14]. These viruses are structurally different: RSV (superfamily Mononegaviridae), is an enveloped virus with negative single-stranded RNA genome and ADV (family Adenoviridae), are a non-enveloped viruses with double-stranded DNA genome. While RSV is the main cause of bronchiolitis and pneumonia in infants and small children, ADV are commonly responsible for mild acute illness of the respiratory system [14-18]. In the present study it was investigated the effect of RSV and ADV infection in respiratory epithelium cell lines on the production of $h \beta D-2$. The results suggest that both viruses induce $\mathrm{h} \beta \mathrm{D}-2$ production, and its presence reduces the replication process and the cytopathic effect (CPE) of these viruses.

\section{Materials and Methods}

\section{Cell cultures}

The HEp-2 human laryngeal epithelioma type 2 cells (ATCC CCL-23, USA) and A549 human alveolar type II-like epithelial cells (ATCC, CCL-185 USA), were acquired from American Type Culture Collection (Manassas, VA). Cell lines were propagated in $25 \mathrm{~cm}^{3}$ flasks (Nunc Thermo Scientific, Hanover Park, ILL) and Petri dishes with Eagle's Minimal Essential Medium (MEM), supplemented with $10 \%$ fetal bovine serum and antibiotics (Penicillin $100 \mathrm{U} / \mathrm{mL}$, Streptomycin $100 \mu \mathrm{g} / \mathrm{mL}$, Amphotericin-B $1 \mu \mathrm{g} / \mathrm{mL}$; Invitrogen Life Technologies, Gaithersburg, MD). Cells were maintained at $37^{\circ} \mathrm{C}$ in $5 \% \mathrm{CO}_{2}$ atmosphere and were stored and grown in accordance with the manufacturer's instructions. WRL 68 Human liver embryo (ATCC CCL-48, ECACC catalog code: 89121403 USA), this was used as a negative control.

*Corresponding author: Carlos Cabello-Gutierrez, National Institute of Respiratory Diseases, Ismael Cosio Villegas, Calzada de Tlalpan 4502, México DF114080, Mexico, Tel: +525 55487 1700; Ext.: 5123; E-mail: tajincg@yahoo.com.mx

Received July 30, 2015; Accepted August 20, 2015; Published August 24, 2015

Citation: Galván Morales MÁ, Gutiérrez AE, Rosete Olvera DP, Gutiérrez CC (2015) Effect of Human Beta Defensin-2 in Epithelial Cell Lines Infected with Respiratory Viruses. J Bioanal Biomed 7: 136-143. doi:10.4172/1948-593X.1000135

Copyright: (C 2015 Galván Morales MÁ, et al. This is an open-access article distributed under the terms of the Creative Commons Attribution License, which permits unrestricted use, distribution, and reproduction in any medium, provided the original author and source are credited. 


\section{RSV and ADV propagation}

RSV Long strain and ADV serotype 5 isolated from a male rhinofaringitis patient, 6 years old, were disseminated in confluent monolayers of HEp-2 and A549 cells in $25 \mathrm{~cm}^{3}$ flasks. Monolayers of each cell line were washed twice with sterile PBS $(5 \mathrm{~mL})$; two groups were formed and each one was inoculated with each virus at a multiplicity of infection of $0.01 \mathrm{PFU} / \mathrm{mL}$. After incubation for $2 \mathrm{~h}$ at $37^{\circ} \mathrm{C}$ in a wet chamber with $5 \% \mathrm{CO}_{2}$ atmosphere, the inoculum was removed by centrifugation, washed and incomplete medium (without serum) was added. Incubation in the same conditions as described was followed until the appearance of the CPE distinctive of each virus was detected. Once the maximum degree of such effect was reached, each virus was harvested and three aliquots were prepared, one was used for virus titration by plaque assay with HEp-2 cells, other was exposed to ultraviolet (UV) light for $15 \mathrm{~min}$ for its use as control, and the remaining aliquot was transferred to $1.5 \mathrm{~mL}$ cryotubes and stored at $-70^{\circ} \mathrm{C}$.

\section{RSV and ADV inactivation}

An aliquot of each virus ( $5 \mathrm{~mL}$ of virus at $\left.610^{6} \mathrm{PFU}\right)$ in serum-free medium (RPMI) was placed in a sealed box and irradiated for $10 \mathrm{~min}$ at a distance of $10 \mathrm{~cm}$ with optimal radiation levels $(1,200$ units $100 \mu \mathrm{J} /$ $\mathrm{cm}^{2}$ ), using an FB-UVXL 1000 UV cross-linker Fisher Biotech (Thermo Fisher Scientific) as previously described. Complete viral inactivation was verified by plaque assay on monolayers of HEp-2 and A549 cells.

\section{RSV and ADV titration by lytic plaque assay}

HEp-2 cells in $25 \mathrm{~cm}^{3}$ flask were trypsinized and resuspended in $11 \mathrm{~mL}$ of MEM supplemented with $10 \%$ fetal bovine serum. A 24-well multidish plate was filled with $0.5 \mathrm{~mL}$ per well of the cell suspension and incubated at $37^{\circ} \mathrm{C}$ with $5 \% \mathrm{CO}_{2}$. Confluent monolayers were inoculated with $100 \mu \mathrm{L}$ of different dilutions of RSV or ADV (in serumfree medium from $10^{-0}$ up to $10^{-8}$ ), in duplicate tests and incubated for $2 \mathrm{hr}$ at $37^{\circ} \mathrm{C}$ with $5 \% \mathrm{CO}_{2}$. Viral inoculum was eliminated, monolayers were washed, and $1.5 \mathrm{~mL}$ of incomplete medium with sterile $2.5 \%$ methylcellulose per well were added and incubated in a wet chamber with $5 \% \mathrm{CO}_{2}$ at $37^{\circ} \mathrm{C}$, until $\mathrm{CPE}$ was observed (6-8 days). Viral titration was done counting directly the number of lytic plaques observed in the highest dilution, considering the dilution factor $(\mathrm{PFU} / \mathrm{mL}=$ number of plaques $\times \mathrm{df} \times 10$ ), where $\mathrm{df}$ is the dilution factor and 10 is the correction factor corresponding to $0.1 \mathrm{~mL}$ of the inoculum.

\section{Quantitation $\mathrm{h} \beta \mathrm{D}-2$ in infected cells}

Medium was removed from confluent monolayers of cultured cells by suction and washed twice with PBS. Cells were divided in two groups and each one was separately infected with RSV or ADV, at infective doses of 1.0 PFU. Afterwards, at different times $(5,15,30$, 45, 60, 90 and $120 \mathrm{~min}$ ), monolayers were washed twice with cold PBS and harvested with harvest buffer $\left(50 \mathrm{mM} \mathrm{NaF}, 10 \mathrm{mM} \mathrm{Na} \mathrm{MoO}_{4}\right.$, $\mathrm{Na}_{3} \mathrm{VO}_{4}$ and $1 \mathrm{mM}$ EDTA). Cells were transferred to $1.5 \mathrm{~mL}$ Eppendorf tubes and centrifuged at $1200 \times g$ for $10 \mathrm{~min}$ at $4^{\circ} \mathrm{C}$. Supernatants were removed by suction and the cell pellets were resuspended in a RIPA $2 \mathrm{X}$ hypotonic solution with phosphatase and protease inhibitors (2.5-10 $\mu \mathrm{g} / \mathrm{mL}$ aprotinin and $2.5-1 \mu \mathrm{g} / \mathrm{mL}$ leupeptin) in $500 \mu \mathrm{L}$ total volumes. Total proteins were quantified using the Bradford method, separated in $18 \%$ sodium dodecyl sulfate polyacrylamide gel electrophoresis (SDSPAGE), and transferred to nitrocellulose membrane for Westernblot analysis. Presence of transferred proteins was visualized by $0.1 \%$ Ponceau red staining in 5\% acetic acid. Membranes were blocked with a 5\% skimmed milk solution and $0.1 \%$ Tween 20 in TBS for 2 h. Subsequently, membranes were incubated with $1 \%$ bovine serum albumin $(3 \mathrm{~mL})$ and rabbit anti-h $\beta \mathrm{D}-2$ polyclonal IgG antibody at a $1: 1000$ dilution, and incubated overnight at $4^{\circ} \mathrm{C}$. Reaction was detected by incubating the membranes with anti-IgG peroxidase-coupled at a 1:300 dilution and developed by chemiluminescence on an X-ray film with luminol; bands were analyzed by densitometry. Monoclonal IgG1 anti-actin antibody was used as control. All antibodies were purchased from Santa Cruz Biotechnology (Santa Cruz, CA).

\section{RT-PCR assays}

Cultures of A549 and HEp-2 cells were infected with RSV and ADV, respectively. Total RNA was isolated by using TRIzol (Invitrogen, Carlsbad, CA) following the manufacturer's protocol. A $3.0 \mu \mathrm{g}$ of total RNA was reverse-transcribed for subsequent PCR amplification in a volume of $20 \mu \mathrm{L}$, including 200U M-MLV RT (Moloney murine leukemia virus reverse transcriptase, Invitrogen), $50 \mathrm{U}$ of RNase inhibitor (Sigma-Aldrich St Louis, MO), oligo (dT) (500 $\mu \mathrm{g} / \mathrm{mL}$ Promega, Madison, WI) $(1 \mu \mathrm{L}$ per tube), $10 \mathrm{mM}$ of dNTP Mix (Invitrogen), and $5 x$ first-strand buffer $(250 \mathrm{mM}$ Tris- $\mathrm{HCl}, \mathrm{pH}$ 8.3; $375 \mathrm{mM} \mathrm{KCl} ; 15 \mathrm{mM} \mathrm{MgCl}_{2}$ ) provided by Life Technologies. The reaction was incubated at $37^{\circ} \mathrm{C}$ for $50 \mathrm{~min}$. The inactivation was done by heating at $70^{\circ} \mathrm{C}$ for $15 \mathrm{~min}$. A $20 \mu \mathrm{L}$ portion of the RT products was then brought to a volume of $20 \mu \mathrm{L}$ containing $10 \mathrm{mM}$ of each dNTP, $1 \mathrm{U}$ of Taq polymerase (Promega), 20 pmol of both the upstream and downstream PCR primers, and $1 \times$ PCR buffer (Promega proprietary formulation supplied at $\mathrm{pH} 8.5$ containing blue dye and yellow dye).

The oligonucleotides reported by Schröder et al. [19] were used, which comprise the intron specific region of $\mathrm{h} \beta \mathrm{D}-2$. The sequence for the sense oligonucleotide is 5'-CCAGCCATCAGCCATGAGGGT-3' and anti-sense sequence is 5'-GGAGGCCTTTCTGAATCCGCA-3' with a product of 255 bp. For glyceraldehyde-3-phosphate dehydrogenase (GAPDH); the forward primer was 5'-CCAGCCGAGCCACATCGCTC-3'; and the reverse primer was 5'-ATGAGCCCCAGCCTTCTCCAT-3', giving a 360 bp PCR product. The GAPDH was amplified in the same reaction to serve as the reference gene. Amplification was carried out in a Biometra Personal Thermal Cycler (Biometra, Goettingen, Germany) after an initial denaturation at $94^{\circ} \mathrm{C}$ for $5 \mathrm{~min}$. This was followed by 30 cycles of PCR using the following temperature and time profile: denaturation at $94^{\circ} \mathrm{C}$ for $1 \mathrm{~min}$, primer annealing at $52^{\circ} \mathrm{C}$ for $1 \mathrm{~min}$, primer extension at $72^{\circ} \mathrm{C}$ for 1 min, and a final extension of $72^{\circ} \mathrm{C}$ for $10 \mathrm{~min}$. The PCR products were visualized by electrophoresis on a $2 \%$ agarose gel stained with ethidium bromide $(0.5 \mu \mathrm{g} / \mathrm{mL})$ and visualized by UV transillumination.

\section{Effect of $h \beta D-2$ on viral replication}

HEp-2 and A549 cells were cultured in 24-well plates. Once the monolayer was formed, the medium was removed and $1 \mathrm{~mL}$ of MEM was added to the wells in the first vertical row, and $900 \mu \mathrm{L}$ to the remaining. Later on, recombinant protein $\mathrm{h} \beta \mathrm{D}-2$ (Bioclone, San Diego, CA) was added to the wells from the third vertical row at increasing concentrations of $0.2 \mu \mathrm{g} / \mathrm{mL}$ to $0.5 \mu \mathrm{g} / \mathrm{mL}$ up to the last row. A constant volume of $100 \mathrm{~L}$ of the corresponding titrated virus was added from the second row. Samples were incubated at $37^{\circ} \mathrm{C}$ in $5 \% \mathrm{CO}_{2}$ for $2 \mathrm{~h}$. Following incubation, supernatant was removed, washed with sterile PBS and $1 \mathrm{~mL}$ of $1.5 \%$ methylcellulose was added to each well; samples were again incubated at $37^{\circ} \mathrm{C}$ with $5 \% \mathrm{CO}_{2}$ until lytic plaques were formed. Methylcellulose was removed and samples were washed again, and $200 \mu \mathrm{L}$ of $75 \%$ methanol were added. After $15 \mathrm{~min}, 1 \%$ crystal violet was added for $15 \mathrm{~min}$, washed with water, and lytic plaques were counted using a microscope. Adding the antibody for the inhibition of 
Citation: Galván Morales MÁ, Gutiérrez AE, Rosete Olvera DP, Gutiérrez CC (2015) Effect of Human Beta Defensin-2 in Epithelial Cell Lines Infected with Respiratory Viruses. J Bioanal Biomed 7: 136-143. doi:10.4172/1948-593X.1000135

recombinant hBD-2 protein antibody was used anti- $\beta$-defensin 2 (FL64) rabbit polyclonal IgG Santa Cruz Inc. (Minneapolis, MN, USA).

\section{Quantification of hBD-2}

The A549 and HEp-2 cells with fetal calf serum were infected with RSV and ADV 0.1 MOI, supernatants were collected at different times $(5,15,30,45,60,90$, and $120 \mathrm{~min})$. For ELISA with these infected cells supernatants, 96-well ELISA plates (Immulon 4; Thermo Labsystems, Beverly, MA) were coated at $37^{\circ} \mathrm{C}$ for $1 \mathrm{~h}$ with $10 \mu \mathrm{L}$ of each supernatant fraction or controls (recombinant $\mathrm{h} \beta \mathrm{D}-2$ or uninfected HEp-2 and A549 cells), in $100 \mu \mathrm{L}$ of $0.1 \mathrm{M}$ sodium bicarbonate buffer, $\mathrm{pH}$ 10.6. Wells were washed with PBS-0.05\% Tween and blocked with $1 \%$ bovine serum albumin in PBS for $1 \mathrm{~h}$ at room temperature. Plates were washed twice with PBS- $0.05 \%$ Tween, and wells were incubated with $100 \mu \mathrm{L}$ of rabbit polyclonal anti-h $\beta \mathrm{D}-2$ antibody (Santa Cruz, Minneapolis, MN) diluted 1:3,000 in $0.1 \mathrm{M}$ carbonate buffer $(\mathrm{pH}$ 9.6), for $1 \mathrm{~h}$ at room temperature. After three washes with PBS- $0.05 \%$ Tween, $100 \mu \mathrm{L}$ of a 1:3,000 dilution of goat anti-rabbit IgG horseradish peroxidase (HRP) conjugate (Sigma-Aldrich) per well was incubated for $1 \mathrm{~h}$ at room temperature. Plates were washed again three times with PBS- $0.05 \%$ Tween and filled with $100 \mu \mathrm{l}$ of peroxidase substrate (3,3,5,5'-Tetramethylbenzidine (TMB), Sigma. Aldrich), $0.01 \mathrm{M}$ in $0.1 \mathrm{M}$ citrate-phosphate buffer, $\mathrm{pH} 5.0$, containing $0.001 \%$ [vol/vol] $\mathrm{H}_{2} \mathrm{O}_{2}$ )/well. The enzymatic reaction was stopped with $2 \mathrm{M}$ sulfuric acid, and absorbance at $492 \mathrm{~nm}$ was determined in an ELISA reader spectrophotometer (Thermo Lab Systems, Santa Rosa, CA). The ELISA was sensitive to $0.3 \mathrm{ng}$ of $\mathrm{h} \beta \mathrm{D}-2$ /well.

\section{Statistic analysis}

Data were tested for normality. A comparison test (paired student t) was performed. A $P$ value $<0.05$ was considered to indicate a statistically significant difference.

\section{Results}

\section{$\beta$-defensin-2 secretions in cell lines infected with RSV}

Active production of h $\beta \mathrm{D}-2$ in HEp-2 and A549 cells infected with RSV was demonstrated by Western blot and PCR (Figure 1). Cell culture controls uninfected or with UV-inactive viruses, showed a basal production of $\mathrm{h} \beta \mathrm{D}-2$ (mRNA) (Figure $1 \mathrm{D}$ and $1 \mathrm{H}$ lane 2), amount that was subtracted from the results with active viruses. With RSV and ADV, a gradual increase of $h \beta D-2$ was found either by protein presence and mRNA expression. Measured by the two techniques, the maximum production of $\mathrm{h} \beta \mathrm{D}-2$ in HEp-2 cells was 120 min (Figure $1 \mathrm{~A}$ and $1 \mathrm{E}$ ). These results were confirmed by densitometry (Figure $1 \mathrm{~B}$ and 1G). The expression of actin and GAPDH (controls) were similar at all times (Figure 1B-1F actin and $1 \mathrm{D}$ and $1 \mathrm{H} \mathrm{GADPH}$ ). Results of $\mathrm{h} \beta \mathrm{D}-2$ production in infected A549 and HEp-2 are presented in Figure 1. Similar secretory behavior was found in both cell lines, except that $\mathrm{h} \beta \mathrm{D}-2$ secretion evaluated by Western blot was observed in less than 30 and 45 min (Figure 1A), HEp-2 line cell in comparison with A549 cell (Figure 1E). As in the HEp-2 cells, in A549 cells the expression of internal controls was similar.

\section{$\beta$-defensin-2 productions in cell lines infected with ADV}

In the Western blot test, $\mathrm{h} \beta \mathrm{D}-2$ secretion in HEP-2 cells infected with ADV was higher at 60 and 90 min followed for a slight decrease at $120 \mathrm{~min}$ (Figure 2A), whereas RT-PCR secretion increased from $45 \mathrm{~min}$ (Figure 1D). The expression of controls was similar at all times (Figures 2B and 2D). Regarding A549 cells, the results were similar to those of the HEp-2 cells for the secretion of $\mathrm{h} \beta \mathrm{D}-2$ and for the expression

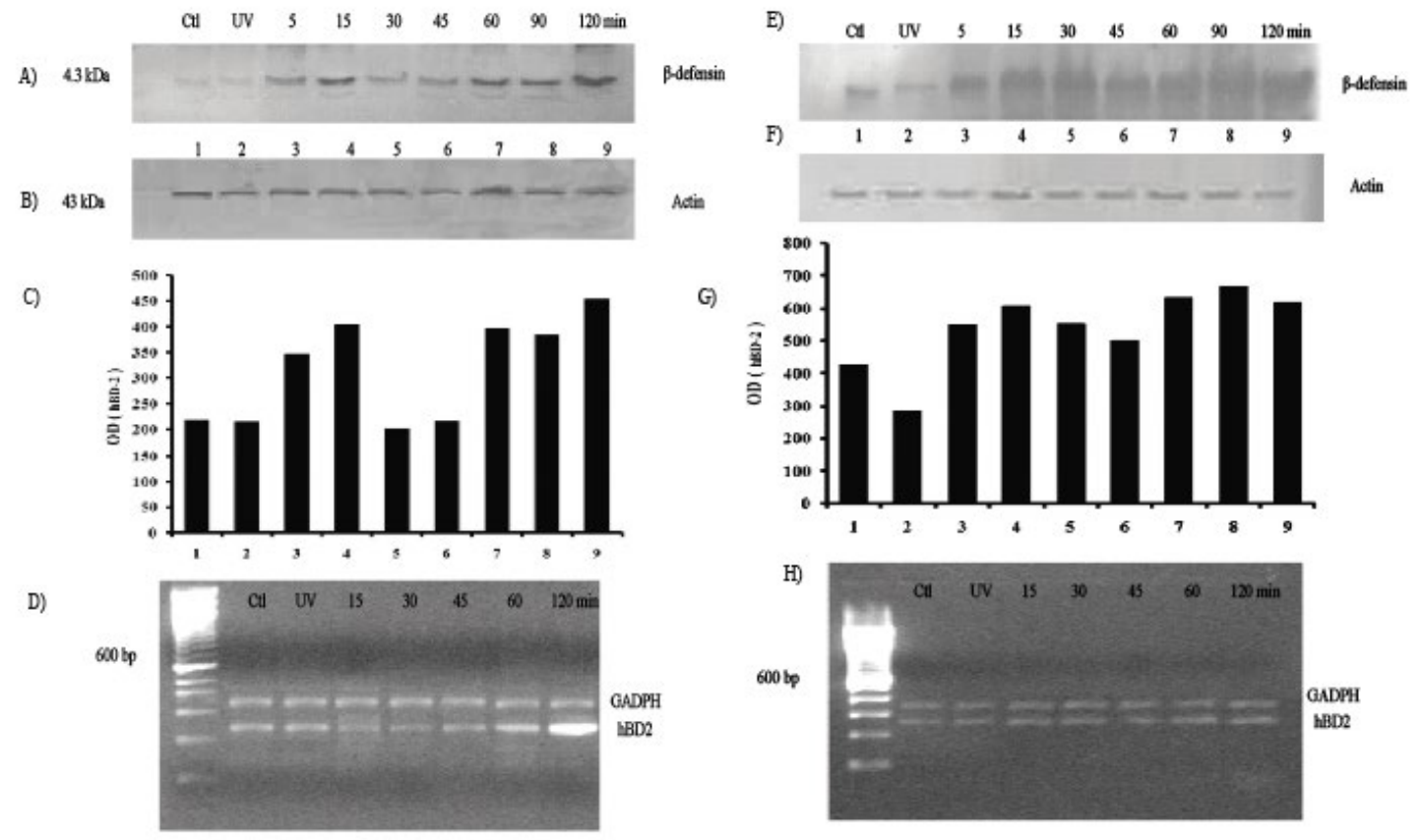

Figure 1: Western blot analysis and RT-PCR of hBD-2 gene expression in HEp-2 and A549 cells infected with RSV: Detection and evaluation by Westernblot of h $3 \mathrm{D}-2$ protein in (A) HEp-2 and (E) A549 cell lines infected with RSV. (B) and (F) Viruses inactivated with UV were used as negative controls and a constitutive protein and Actin, were used as positive controls. (C) and (G) Densitometry of the Western-blot product is shown in the lower part. (D) and (H) h $\beta D-2$ product ( 255 bp) by RT-PCR inHEp-2cells infected with RSV. Lane 1: molecular weight marker (MW); Lane 2: negative control; Lane 3: cells infected with RSV inactivated with UV; Lanes 4-8: cells infected at 15, 30, 45, 60 and 120 min; GAPDH was used as amplification control (360 bp). All assays were performed by triplicate. 


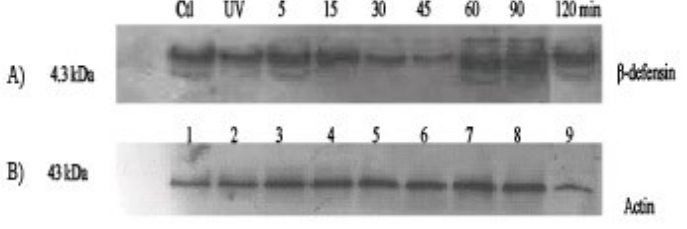

C)

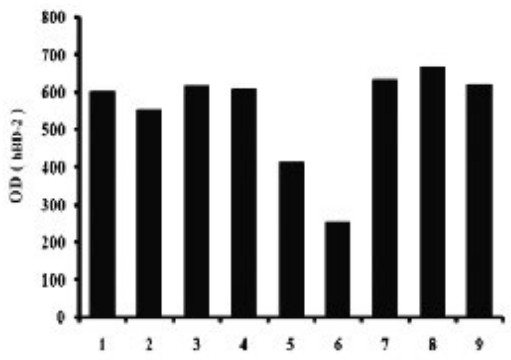

D)

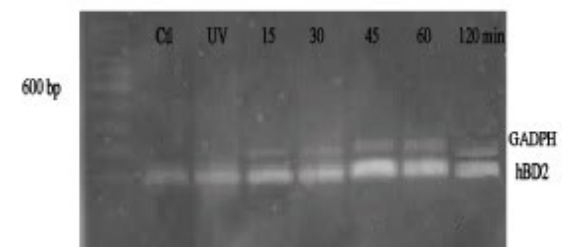

E)

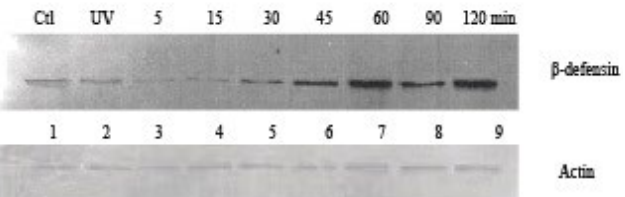

G)

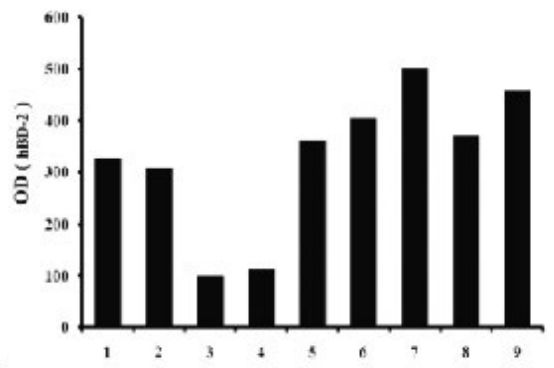

H)

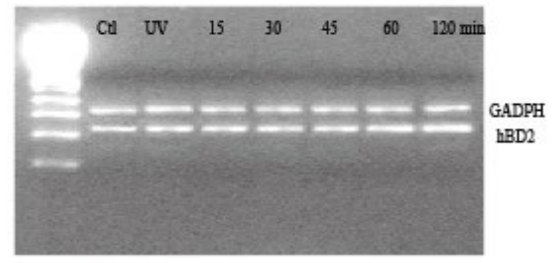

Figure 2: RT-PCR and Western blot analysis of the h $\beta D-2$ gene expression in A549 cells infected with Adenovirus: Detection and evaluation of $h \beta D-2$ protein in HEp-2 (A) and A549 cells (E) infected with ADV time kinetics by Western blot. Viruses inactivated with UV were used as negative control and Actin was used as positive control (B: HEp-2 cell, F: A549 cell). Densitometry of the Western blot product is shown in C: HEp-2 cell and G: A549 cell. hßD-2 product (255 bp) by RT-PCR in HEp-2 (D) and A549 (H) cells infected with ADV. Lane 1: MW marker; Lane 2: negative control; Lane 3: cells infected with RSV inactivated with UV; Lanes 4-8: cells infected with RSV at 15, 30, 45, 60 and $120 \mathrm{~min}$; GAPDH (360 pb) was used as amplification control. All assays were performed by triplicate.

of the internal control (Figures $1 \mathrm{E}, 1 \mathrm{~F}$ and $1 \mathrm{D}$ ). Figure $3 \mathrm{~A}$ shows the Western blot results of non-infected cell cultures harvested at same times as those of the former tests $(5,15,30,45,60,90$ and $120 \mathrm{~min})$. To confirm the constitutive protein production, WRLL8 cells lacking $\mathrm{h} \beta \mathrm{D}-2$ expression were infected with ADV and the result showed the absence of $\mathrm{h} \beta \mathrm{D}-2$ expression and production (Figure $3 \mathrm{~B}$ ).

\section{Statistic analysis densitometry}

The expression of $\mathrm{h} \beta \mathrm{D}-2$ after infection with RSV is higher in the cell line A549 (548.3 \pm 100.2$)$ than in the cell line HEp-2 (311.3 \pm 103.9$)$. According to the test performed values are normally distributed and the comparison of means through a t-paired, showed highly significant differences $(\mathrm{P}=0.000004)$. While infection with $\mathrm{ADV}$ in the increased expression of this $\mathrm{h} \beta \mathrm{D}-2$ occurred in the cell line HEp-2 (568 \pm 98.9$)$, being smaller in A549 cells (326.2 \pm 143.9). The values were normally distributed and the comparison of means through a t-paired showed significant differences $(\mathrm{P}=0.005728)$.

\section{Effect of $\beta$-defensin-2 on viral replication}

HEp- 2 and A549 cells exposed to recombinant $\mathrm{h} \beta \mathrm{D}-2$ at different doses and infected with RSV and ADV, showed a decrease in the formation of lytic plaques compared to the control that was not treated with the protein. The lower formation of lytic plaques occurred with the maximum dose of recombinant $\mathrm{h} \beta \mathrm{D}-2$. The control of infected cells without recombinant $\mathrm{h} \beta \mathrm{D}-2$, presented complete destruction of the monolayer, in contrast with control with non-infected cells, where monolayers remained healthy and confluent (Figure 4). A second trial where A549 cells were cultured in a single 24 wells plate, was performed with viruses at MOI of 0.1 ; in the first row RSV was placed and ADV in the third one. Thereafter, $0.5 \mu \mathrm{g}$ of recombinant $\mathrm{h} \beta \mathrm{D}-2$ protein was added in the wells of both rows, resulting in a complete inhibition of the viral activity in the first row (RSV infection), and partially in the third one (ADV infection) Figure 5. To confirm the role of $h \beta D-2$ as inhibitor of the viral CPE, antibodies against $\mathrm{h} \beta \mathrm{D}-2$ at different doses ( $1 \mu \mathrm{L}$ to $5 \mu \mathrm{L}-0.2 \mu \mathrm{g} \mathrm{g}^{-1}$ ) diluted 1:1000.

\section{HBD-2 production in cell lines infected with RSV and ADV}

The HEp-2 and A549a cell lines with fetal bovine serum were infected with RSV and ADV virus at different times. To be quantified concentration secretion of the supernatant, there was an increase in hBD-2 secretion function of time (Figures 6A and 6B). Higher secretion of $\mathrm{h} \beta \mathrm{D}-2$ in $\mathrm{A} 549$ and HEp- 2 cells was observed at $120 \mathrm{~min}$ post-infection with one and other viruses $(0.25 \mathrm{ng} / \mathrm{mL}$ in HEp- 2 cells and $0.19 \mathrm{ng} / \mathrm{mL}$ on A549 cells). Statistical analysis of $\mathrm{h} \beta \mathrm{D}-2$ secretion in both cells types showed significant differences $(\mathrm{P}<0.05)$ in comparison with controls.

\section{Discussion}

A major feature of an adequate host protection system is the effective resistance to the constant changes of the wide spectrum of infectious agents capable to live and multiply themselves in epithelial surfaces. By far, in all over the world viral respiratory tract infections are the most frequent infectious conditions, ranging from autolimited illness to severe life-threatening infections. The activation of the innate immune system responses in the respiratory tract could be enough to fight against viral invasions and expansion, and also are necessary to establish favorable conditions to activate the adaptive immune system, which in turn contributes for effective viral clearance $[20,21]$. It is well known that responses to viral airways infections, like those elicited by RSV and ADV, are largely restricted to the mucosal 
A)

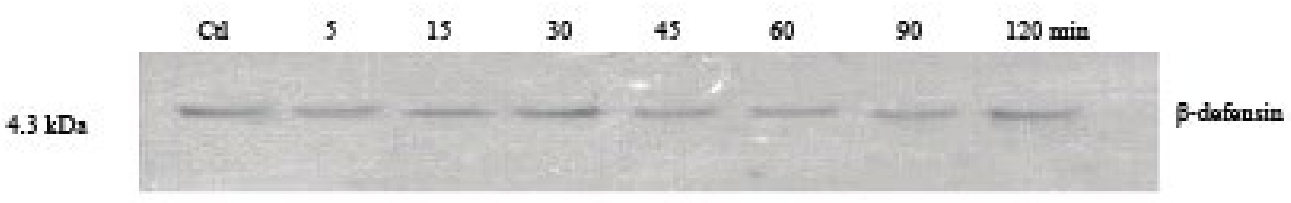

B)

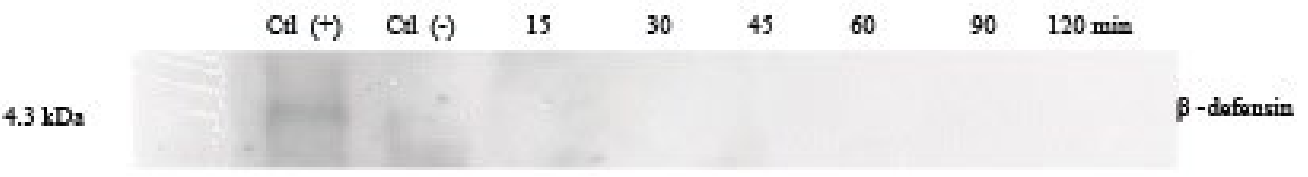

Figure 3: (A) Western-blot of non-infected HEp-2 cells at $0,15,30,45,60$ and 120 min. (B) h $\beta D-2$ secretion by WRL 68 cells infected with ADV virus.

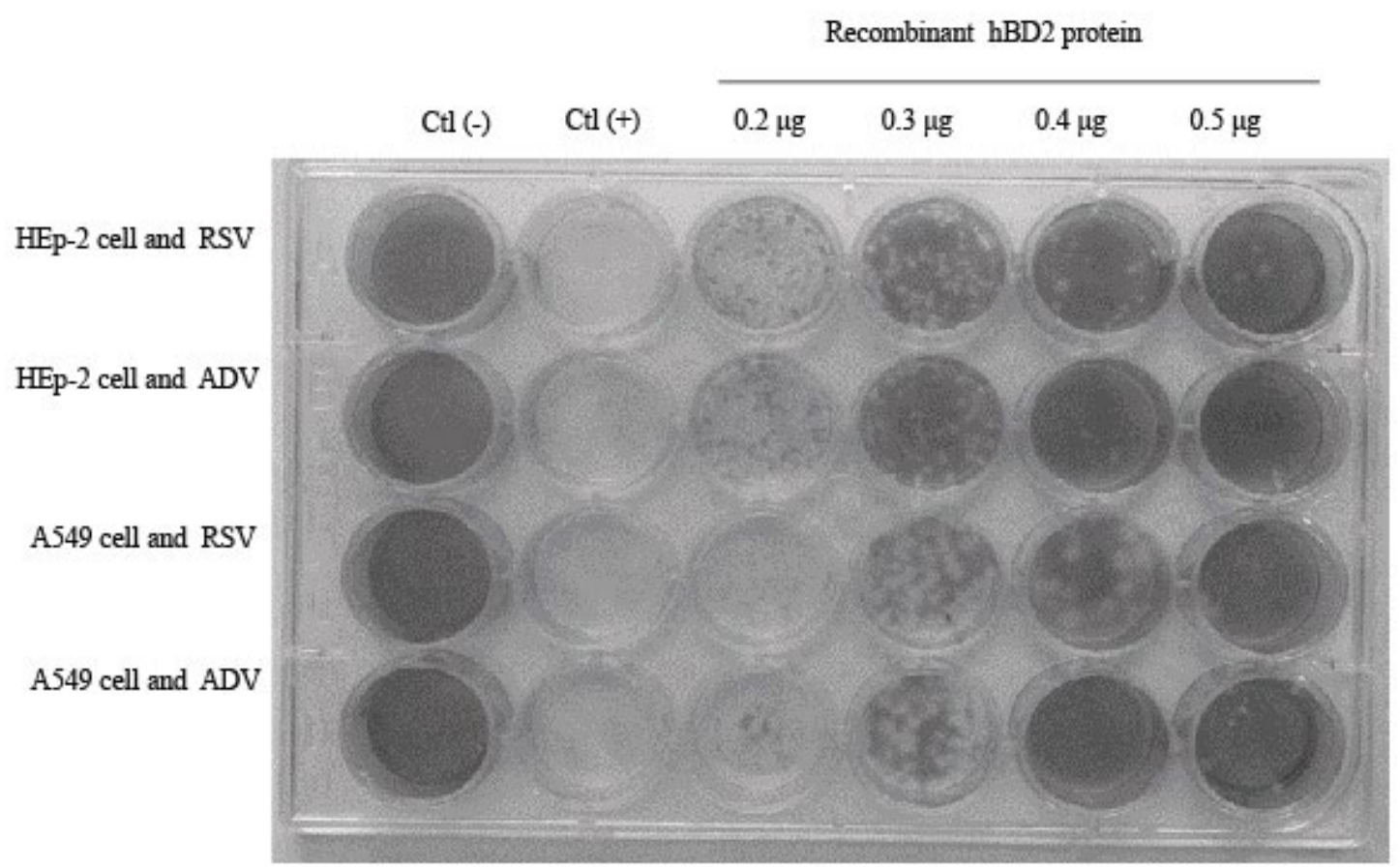

Figure 4: Evaluation of the $\beta$-defensin-2 effect on viral infection by plaque assay. Row 1 vertical: Negative controls: cells without virus; Row 2 vertical: Positive control (virus $0.01 \mathrm{PFU} / \mathrm{mL}$ ); Rows $3,4,5$ and 6 different concentrations of h $\beta \mathrm{D}-2$, from $0.2 \mu \mathrm{g}$ to $0.5 \mu \mathrm{g}$. All assays were performed by triplicate.

compartment and local responses are able to control the infectious processes [11,18]. The results of this study provides support for this concept by demonstrating that RSV and ADV infections of epithelial cells in vitro induces production of $\mathrm{h} \beta \mathrm{D}-2$, a peptide that could play a central role in innate and specific immune responses activation and as an important component of the antiviral response during infection to limit the spread both viral types. RSV and ADV infection of the A549 and HEp- 2 cell lines, induces the secretion of $\mathrm{h} \beta \mathrm{D}-2$ with a limiting factor dependent of the time of exposure to the virus; less secretion as lower exposure time. The use of high doses of recombinant $h \beta D-2$ decreases cytopathic effect of viral infection.

Here, the results confirm that the AVD and RSV infection of epithelial cells induce $\mathrm{h} \beta \mathrm{D}-2$ production, which is involved in the decrease of the infection processes. The overall results were not different in the experiments with any of the viruses, suggesting that protein detection corresponds to the gene behavior. In both cases, the longer 
Citation: Galván Morales MÁ, Gutiérrez AE, Rosete Olvera DP, Gutiérrez CC (2015) Effect of Human Beta Defensin-2 in Epithelial Cell Lines Infected with Respiratory Viruses. J Bioanal Biomed 7: 136-143. doi:10.4172/1948-593X.1000135

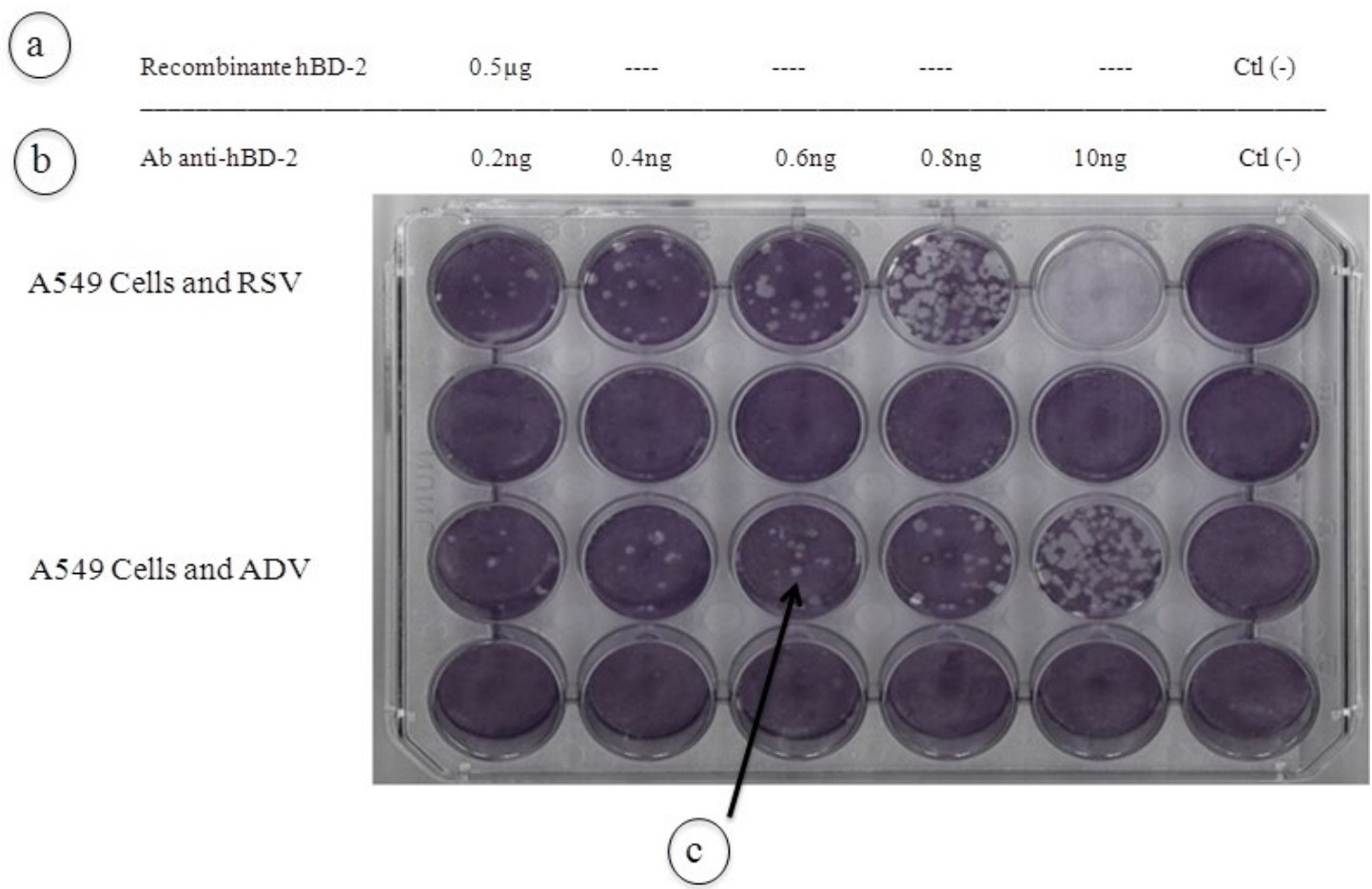

Figure 5: Assay plate lytic anti-Ab hBD- 2. A 24-well plate with A549 cells, initially each lytic plaque was associated with a single particle of infectious virus. The number of inoculated virus particles was determined by dilution. This method was performed to determine the activity of recombinant $h \beta D-2$. (A) Amount of recombinant $\mathrm{h} \beta \mathrm{D}-2$ inoculated; $(\mathrm{B})$ dilutions of anti-h $\beta \mathrm{D}-2$ and $(\mathrm{C})$ plaque forming unit produced by the viral inoculum. All assays were performed by triplicate.

A)

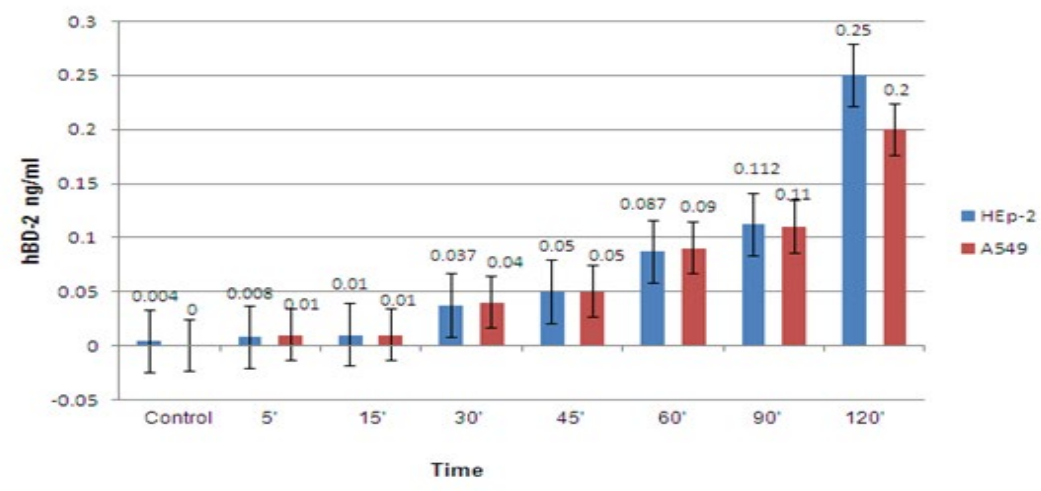

B)

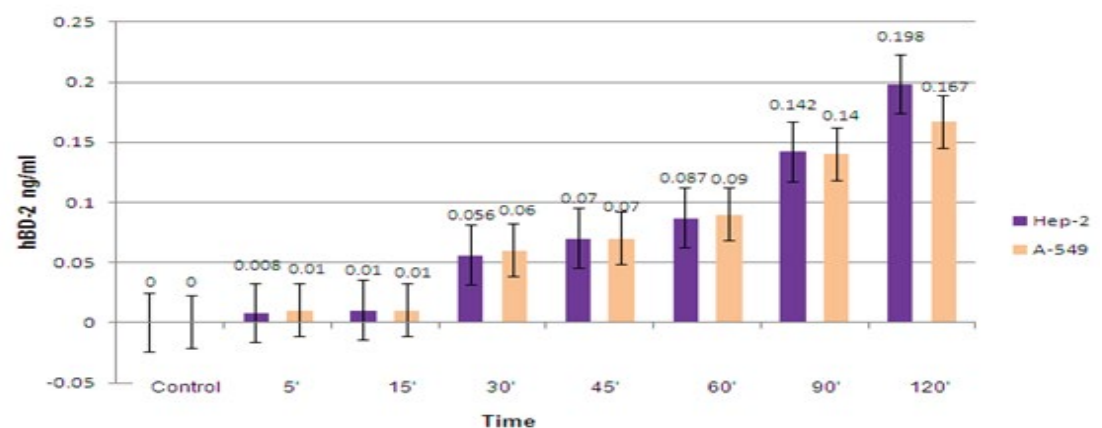

Figure 6: Kinetics of hBD-2 secretion Infection with RSV and ADV by ELISA. Secretion hßD-2 quantified by ELISA in supernatant of A549 and HEp-2 cells treated with fetal calf serum and infected with RSV (A) and with ADV (B). The concentration of hBD-2 at different times is displayed. In blue, results of supernatant from HEp-2 cells and in red, fro, A549 cells. hBD-2 levels increased with time in both cell lines and peaked at 120 min. Data are shown as means of triplicate assays from three separate experiments. Controls are uninfected cells of both types. 
the time of viral exposure, the higher $\mathrm{h} \beta \mathrm{D}-2$ synthesis. Kinetic analysis revealed that there was an initial $\mathrm{h} \beta \mathrm{D}-2$ increased production, followed by a slight decrease and, finally, increasing again. This observed decrease could be explained as the result of the viral penetration process whose replication mechanisms temporarily stops the cellular machinery or activities to distract transcription. Other possibilities to explain the observed reduction are the depletion of intracellular stores, the average life of the protein or mRNA or the absence of other stimulants for transcription factors activation.

A low level of hD-2 was detected in non-infected cells as well as in cells treated with inactive virus; thus, a kinetics test with the same times was carried out with non-infected cells revealing that, in contrast with the assays with active viruses, the protein constantly remains in its baseline condition [22-24]. This results suggest that in epithelial cells in upper and lower airways, $\mathrm{h} \beta \mathrm{D}-2$ is permanently produced in a baseline value and the presence of viruses, enveloped or non-enveloped, promote the activation of the gene. However, even when $\mathrm{h} \beta \mathrm{D}-2$ synthesis is stimulated, the viral infection is not stopped, most probably because the amount produced during the infection is not enough to counteract the viral replication. Therefore, in order to establish whether or not a higher quantity of $\mathrm{h} \beta \mathrm{D}-2$ had effects on the viruses, plaque assays with recombinant protein-ascending doses were performed. Results revealing that a higher concentration of $\mathrm{h} \beta \mathrm{D}-2$ conducts to a lower cytopathic effect and less viral replication, suggesting that an appropriate quantity of $\mathrm{h} \beta \mathrm{D}-2$ can protect epithelia from the virus effect. However, more experiments are required to determine the adequate protective dose, since some have reported that high $\mathrm{h} \beta \mathrm{D}-2$ doses are cytotoxic [22].

There are some evidences supporting the dual capacity of cationic proteins to eliminate a wide range of infectious agents and to facilitate the adaptive response induction [3,6]. Such peptides are expressed in many species by cells with phagocytic properties and epithelial cells. Reports indicate that such proteins are inducible by the presence of the agent in the medium. Other reports indicate that induction and transcriptional regulation for the synthesis of these proteins are initiated by the interaction between the membranes of the agent and the producer cell [25]; however, there are some doubts, since some agents lacking these structures also induce peptide production [26]. Molecules, such as $\mathrm{h} \beta \mathrm{D}$, have been tested in similar environments and in environments with characteristics other than the natural environment, but to date tests have been limited only to RNA behavior. In this in vitro approach, results suggest that the used cells generate, in contact with both viruses, a stimulus for $\mathrm{h} \beta \mathrm{D}-2$ production, and that this synthesis is relative to the exposure time. Just like with bacterial infections, respiratory viruses induce the $\mathrm{h} \beta \mathrm{D}-2$ production, and $\mathrm{h} \beta \mathrm{D}-2$ reduces the replication and cytopathic effect of both viruses. Therefore, determining the action mechanism of this defensin may help to understand and design strategies to treat and prevent respiratory viral infections. Accordingly with the results here found, is clear that the $\mathrm{h} \beta \mathrm{D}-2$ production is an important defense mechanism that can prevent the spread of infection in the early stages of viral replication. However, should be noticed that in our model, cellular inhibitory effect of viral replication is incomplete because in the system other components of the innate and specific immune responses are absent, nevertheless, it is evident an important partial effect of the $\mathrm{h} \beta \mathrm{D}-2$. Because the enveloped or non-enveloped structure of the viruses seems not be important in regard to the blocking capabilities of $\mathrm{h} \beta \mathrm{D}$, we proposed as one possibility for the application of these results is the use of a low-pathogenicity virus, as ADV is or the respective vaccine, as $\mathrm{h} \beta \mathrm{D}-2$ inducers as therapeutic tools in infectious diseases where this antimicrobial peptide has demonstrated be useful.

\section{Conclusion}

The results of this study demonstrate that infection of A549 and HEp 2 cells by RSV ADV induce production $\mathrm{h} \beta \mathrm{D}-2$. The use of high doses of $h \beta D-2$ inhibits the cytopathic effect generated by viral infection. Apparently, no viral structure appears to be important because both virus infection was blocked by $\mathrm{h} \beta \mathrm{D}-2$.

\section{Acknowledgment}

The authors acknowledge the financial assistance of INER and the authors thank Dr. Ethel A. García-Latorre and Dr. Luis Manuel Terán-Juárez for their invaluable support.

\section{References}

1. Beisswenger C, Bals $R$ (2005) Functions of antimicrobial peptides in host defense and immunity. Curr Protein Pept Sci 6: 255-264.

2. Hwang PM, Vogel HJ (1998) Structure-function relationships of antimicrobial peptides. Biochem Cell Biol 76: 235-246.

3. Wimley WC, Selsted ME, White SH (1994) Interactions between human defensins and lipid bilayers: evidence for formation of multimeric pores. Protein Sci 3: 1362-1373.

4. Fujii G, Selsted ME, Eisenberg D (1993) Defensins promote fusion and lysis of negatively charged membranes. Protein Sci 2: 1301-1312.

5. Trabi M, Schirra HJ, Craik DJ (2001) Three-dimensional structure of RTD-, a cyclic antimicrobial defensin from Rhesus macaque leukocytes. Biochemistry 40: 4211-4221.

6. Wu Z, Hoover DM, Yang D, Boulègue C, Santamaria F, et al. (2003) Engineering disulfide bridges to dissect antimicrobial and chemotactic activities of human beta-defensin 3. Proc Natl Acad Sci USA 100: 8880-8885.

7. Yang D, Chertov O, Bykovskaia SN, Chen Q, Buffo MJ, et al. (1999) Betadefensins: Linking innate and adaptive immunity through dendritic and $\mathrm{T}$ cell CCR6. Science 286: 525-528.

8. Pérez-Cañadillas JM, Zaballos A, Gutiérrez J, Varona R, Roncal F (2001) NMR solution structure of murine CCL20/MIP-3alpha, a chemokine that specifically chemo attracts immature dendritic cells and lymphocytes through its highly specific interaction with the beta-chemokine receptor CCR6. J Biol Chem 276 : 28372-28379.

9. Pazgier M, Hoover DM, Yang D, Lu W, Lubkowski J (2006) Human betadefensins. Cell Mol Life Sci 63: 1294-1313.

10. Klotman ME, Chang TL (2006) Defensins in innate antiviral immunity. Nat Rev Immunol 6: 447-456.

11. Wilson SS, Wiens ME, Smith JG (2013) Antiviral mechanisms of human defensins. J Mol Biol 425: 4965-4980.

12. Schutte BC, McCray PB Jr (2002) [beta]-defensins in lung host defense. Annu Rev Physiol 64: 709-748.

13. Gropp R, Frye M, Wagner TO, Bargon J (1999) Epithelial defensins impairs adenoviral infection: implication for adenovirus-mediated gene therapy. Hum Gene Ther 10: 957-964.

14. Duits LA, Nibbering PH, van Strijen E, Vos JB, Mannesse-Lazeroms SP, et al (2003) Rhinovirus increases human beta-defensin-2 and -3 mRNA expression in cultured bronchial epithelial cells. FEMS Immunol Med Microbiol 38: 59-64.

15. Nair H, Nokes DJ, Gessner BD, Dherani M, Madhi SA, et al. (2010) Globa burden of acute lower respiratory infections due to respiratory syncytial virus in young children: a systematic review and meta-analysis. Lancet 375: 15451555

16. Everard ML (2006) The role of the respiratory syncytial virus in airway syndromes in childhood. Curr Allergy Asthma Rep 6: 97-102.

17. Chau SK, Lee SL, Peiris MJ, Chan KH, Chan E, et al. (2014) Adenovirus respiratory infection in hospitalized children in Hong Kong: serotype-clinical syndrome association and risk factors for lower respiratory tract infection. Eur J Pediatr 173: 291-301.

18. Rodríguez-Martínez CE, Rodríguez DA, Nino G (2015) Respiratory syncytial virus, adenoviruses, and mixed acute lower respiratory infections in children in a developing country. J Med Virol 87: 774-781. 
Citation: Galván Morales MÁ, Gutiérrez AE, Rosete Olvera DP, Gutiérrez CC (2015) Effect of Human Beta Defensin-2 in Epithelial Cell Lines Infected with Respiratory Viruses. J Bioanal Biomed 7: 136-143. doi:10.4172/1948-593X.1000135

19. Schröder JM, Harder J (1999) Human beta-defensin-2. Int J Biochem Cell Biol 31: 645-651.

20. Vareille M, Kieninger E, Edwards MR, Regamey N (2011) The airway epithelium: Soldier in the fight against respiratory viruses. Clin Microbiol Rev 24: $210-229$

21. Bals R (2000) Epithelial antimicrobial peptides in host defense against infection. Respir Res 1: 141-150.

22. Milner SM, Bhat S, Buja M, Gulati S, Poindexter BJ, et al. (2004) Expression of human beta defensin 2 in thermal injury. Burns 30: 649-654.

23. Chong KT, Xiang L, Wang X, Jun EL, Xi LF, et al. (2006) High level expression of human epithelial beta-defensins (hBD-, 2 and 3 ) in papilloma virus induced lesions. Virol J 3: 75.

24. Singh PK, Jia HP, Wiles K, Hesselberth J, Liu L, et al. (1998) Production of beta-defensins by human airway epithelia. Proc Natl Acad Sci USA 95: 14961 14966.

25. Sudheendra US, Dhople V, Datta A, Kar RK, Shelburne CE, et al. (2015) Membrane disruptive antimicrobial activities of human $\hat{i}^{2}$-defensin- 3 analogs. Eur J Med Chem 91: 91-99.

26. Weinberg A, Quiñones-Mateu ME, Lederman MM (2006) Role of human betadefensins in HIV infection. Adv Dent Res 19: 42-48. 